\title{
Gold(III) Aryl Complexes as Reagents for Constructing Hybrid Peptide-Based Assemblies via Cysteine S-Arylation
}

\author{
Julia M. Stauber*, Arnold L. Rheingold, and Alexander M. Spokoyny*
}

\begin{abstract}
Organometallic complexes have recently gained attention as competent bioconjugation reagents capable of introducing a diverse array of substrates to biomolecule substrates. Here, we detail the synthesis and characterization of an aminophosphine-supported $\mathrm{Au}(\mathrm{III})$ platform that provides rapid and convenient access to a wide array of peptide-based assemblies via cysteine $S$-arylation. This strategy results in the formation of robust C-S covalent linkages and is an attractive method for the modification of complex biomolecules due to the high functional group tolerance, chemoselectivity, and rapid reaction kinetics associated with these arylation reactions. This work expands upon existing metal-mediated cysteine arylation by introducing a class of air-stable organometallic complexes that serve as competent bioconjugation reagents enabling the synthesis of conjugates of higher structural complexity including macrocyclic stapled and bicyclic peptides, as well as a peptide-functionalized multivalent hybrid nanocluster. This organometallic-based approach provides a convenient, one-step method of peptide functionalization and macrocyclization, and has the potential to contribute to efforts directed towards developing efficient synthetic strategies of building new and diverse hybrid peptide-based assemblies of high complexity.
\end{abstract}

\section{INTRODUCTION}

Chemical tools that enable the selective and efficient modification of complex biomolecules provide important technologies driving the development of new drugs, diagnostics, and therapeutics relevant to nanomedicine, pharmaceutical and materials sciences, among other fields. ${ }^{1-4}$ Chemical ligation of synthetic groups to specific amino acid residues in biomolecule substrates has proven to be a powerful method for protein and peptide modification; however, challenges in this area arise from the need for specific and controllable chemical processes that can generate stable conjugates under mild, and biologically-compatible reaction conditions. ${ }^{5}$ Transition-metal-mediated arylation reactions have received growing attention in this space as a versatile method of preparing modified peptide and protein conjugates through the formation of robust and covalent $\mathrm{X}-\mathrm{C}\left(\mathrm{sp}^{2}\right)$ linkages $(\mathrm{X}=$ carbon or heteroatom). ${ }^{5-10}$ On account of its high nucleophilicity and relatively low natural abundance, ${ }^{11}$ the thiol side chain of cysteine has become a highly utilized coupling partner for site-selective arylation of biomolecules, leading to a diverse array of peptide and protein bioconjugates (Figure 1A).12,13

In 2015, Buchwald, Pentelute et al. reported an auxiliary-free, metal-assisted approach to chemoselective cysteine $S$-arylation of unprotected peptides and proteins using organometallic Pd(II) complexes supported by biarylphosphine ligands (Figure 1A). ${ }^{14}$ Our group followed this work with the introduction of aminophosphine-based (Me-DalPhos)AuArCl complexes ${ }^{15}$ 17 as air-stable and versatile cysteine arylation reagents (Figure 1B). ${ }^{18}$ The Au(III)-mediated bioconjugation chemistry displays rapid reaction kinetics, high functional group tolerance, and is compatible within a wide $\mathrm{pH}$ range and in the presence of a variety of buffers and solvents. This method enabled the selective introduction of a broad scope of substrates (e.g. drug molecule, affinity tag, fluorophore, poly(ethyleneglycol) polymer) to the cysteine residues of complex biomolecule coupling partners. Here, we have expanded upon this work and introduced a new class of air-stable Au(III) cysteine arylation reagents based on a modified tertbutyl substituted aminophosphine (P,N) ligand framework. This work presents a range of mono-, bi-, tri-, and dodeca-metalated $\mathrm{Au}$ (III) complexes as organometallic building blocks used to prepare various architectures of arylated hybrid peptide assemblies of high complexity and structural diversity including stapled and bicyclic peptides, a small dendrimer, as well as multivalent, three-dimensional inorganic clusters (Figure 1C).
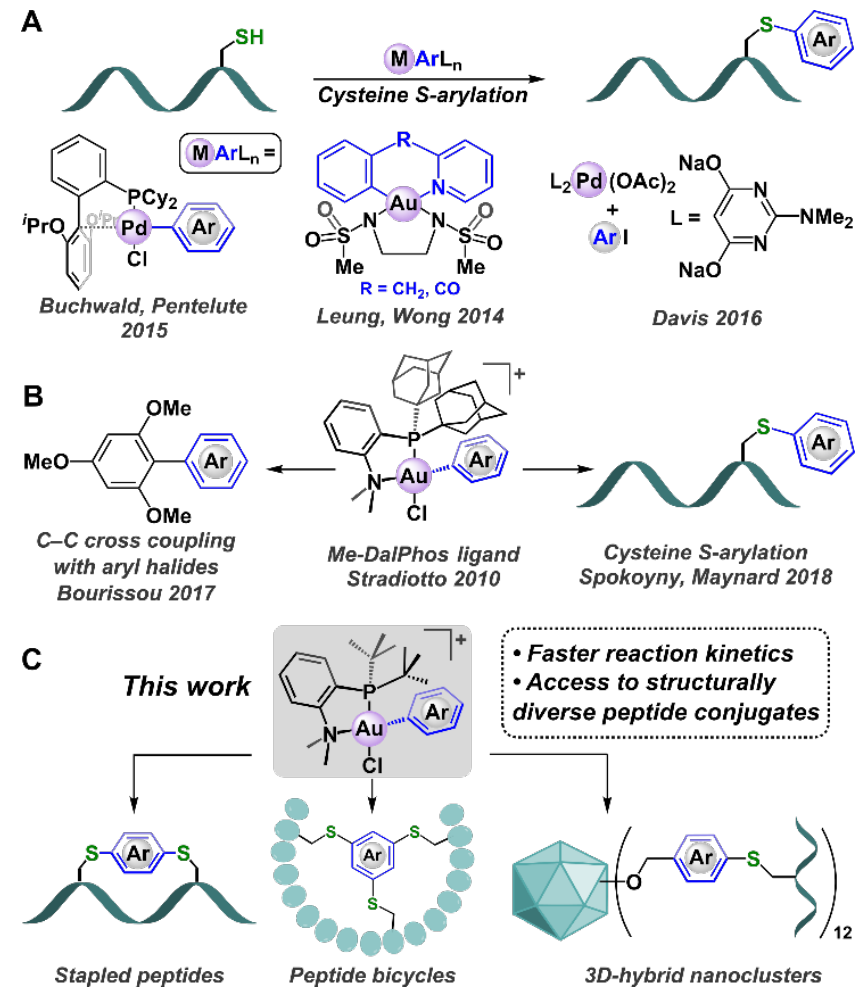

Stapled peptides

$3 D$-hybrid nanoclusters

Figure 1. (A) General metal-mediated cysteine $S$-arylation reaction scheme and key representative transition-metal arylation reagents.9,10,14 (B) Applications of [(Me-DalPhos)AuArCl] ${ }^{+}$complexes in cross-coupling ${ }^{17}$ and cysteine $S$-arylation reactions. ${ }^{18}$ (C). This work, which introduces Au(III) complexes supported by 
the tert-butyl-substituted (P,N) ligand as cysteine arylation reagents used to construct hybrid peptide-based assemblies of high structural diversity and complexity.

\section{RESULTS AND DISCUSSION}

The present di-tert-butyl-substituted aminophosphine $(\mathrm{P}, \mathrm{N})$ ligand (Figure $1 \mathrm{C})$ was first introduced by Stradiotto et al. ${ }^{16,19}$ to support iridium, ${ }^{19}$ palladium, ${ }^{16}$ and gold 15 complexes used in catalytic transformations; however, the gold catalyst was not isolated or characterized in the original report. In this work, we report the synthesis, isolation and characterization of the ditert-butyl-substituted (P,N)Au(I)Cl complex and demonstrate its use in the preparation of $\mathrm{Au}(\mathrm{III})$ cysteine arylation reagents. The $(\mathrm{P}, \mathrm{N})$-supported $\mathrm{Au}(\mathrm{I}) \mathrm{Cl}$ complex was synthesized following methods adapted from a previously reported procedure ${ }^{15}$ through treatment of $\mathrm{HAuCl}_{4} \bullet 3 \mathrm{H}_{2} \mathrm{O}$ with di-tert-butyl(2-dimethylaminophenyl)phosphine in the presence of 2,2'-thiodiethanol, which resulted in clean formation of a single species after workup as assayed by ESI-MS(+) and NMR spectroscopic characterization (SI Section S2.1.1.). An $\mathrm{X}$-ray diffraction analysis conducted on a single, colorless crystal of the product confirmed its identity as the $(\mathrm{P}, \mathrm{N}) \mathrm{Au}(\mathrm{I}) \mathrm{Cl}$ complex (1, SI Section 5.1.). The solidstate structure reveals the nearly idealized linear twocoordinate geometry typical of $\mathrm{Au}(\mathrm{I})$ complexes with a $\mathrm{P}-\mathrm{Au}-\mathrm{Cl}$ angle of $177.20(2)^{\circ}$, which is consistent with $\mathrm{P}-\mathrm{Au}-\mathrm{Cl}$ angles for similarly substituted $\mathrm{Au}(\mathrm{I})$ phosphine complexes reported in the literature.15,20-26 Complex 1 displays excellent stability under open atmosphere conditions and can be handled and stored $(>6$ months) without any indication of degradation.

\section{ARYLATION OF LINEAR PEPTIDES}

Incorporating an approach to enhance the reactivity of $\mathrm{Au}(\mathrm{I})$ centers towards oxidative addition first introduced by Bourissou et al.,17,27 we prepared a series of Au(III) aryl halide complexes through treatment of 1 with electron-rich ( $p$-ethyl, tolyl) and electron deficient ( $p$-fluoro) aryl iodide electrophiles in the presence of the halide scavenger, $\mathrm{AgSbF}_{6}$ (Figure 2A). The reactions proceed to completion within minutes $(<5)$ when conducted under open atmosphere conditions as indicated by ${ }^{31} \mathrm{P}$ NMR spectroscopic monitoring of the crude reaction mixtures. The ${ }^{31} \mathrm{P}$ NMR spectra revealed the disappearance of the resonance corresponding to $\mathbf{1}\left(\delta 55.2 \mathrm{ppm}, \mathrm{CH}_{2} \mathrm{Cl}_{2}\right.$ ), and the appearance of downfield-shifted signals ( $\delta$ 84.3-81.3 ppm, $\mathrm{CH}_{2} \mathrm{Cl}_{2}$ ) attributed to the phosphorus atoms on each respective cationic $\mathrm{Au}(\mathrm{III})$ complex ([1a-c] $\left[\mathrm{SbF}_{6}\right]$, SI Section S2.1.). The AgI byproduct formed in these reactions was easily removed from the crude mixtures via filtration, and the $\mathrm{Au}(\mathrm{III})$ complexes were isolated as pure, air-stable solids after crystallization. The hemilabile nature of the supporting $(\mathrm{P}, \mathrm{N})$ ligand is integral to stabilization of the square planar $\mathrm{Au}(\mathrm{III})$ products through $\kappa^{2}$ ligand coordination via chelation of the $\mathrm{NMe}_{2}$ donor to the $d^{8}$ metal center, ${ }^{17-19,28}$ and an X-ray diffraction analysis of the $[(\mathrm{P}, \mathrm{N}) \mathrm{AuCl}(p$-ethylbenzene $)]\left[\mathrm{SbF}_{6}\right]\left([\mathbf{1 a}]\left[\mathrm{SbF}_{6}\right]\right)$ complex (Figure 2B) confirmed this binding mode.

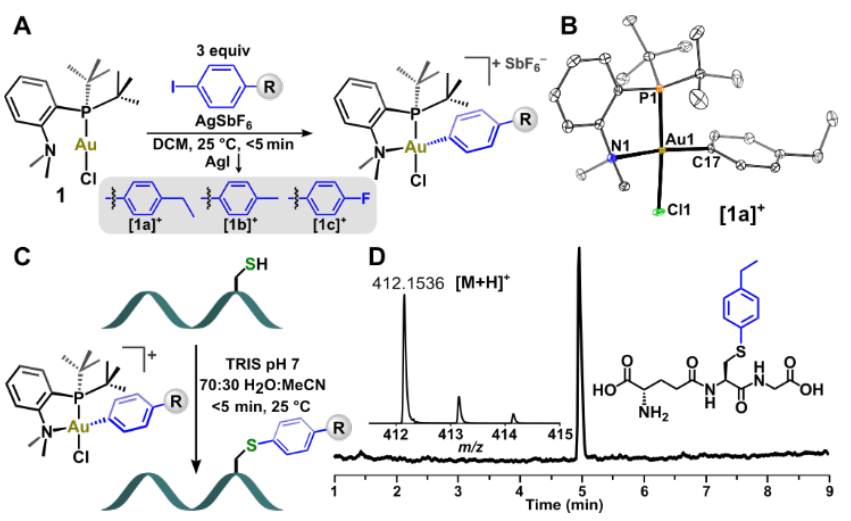

Figure 2. (A) Synthetic scheme for the preparation of $[(\mathrm{P}, \mathrm{N}) \mathrm{Au}(\mathrm{III}) \mathrm{ArCl}]\left[\mathrm{SbF}_{6}\right]$ complexes $\left([\mathbf{1} \mathbf{a}-\mathbf{c}]\left[\mathrm{SbF}_{6}\right]\right)$. (B) Solid-state structure of $[\mathbf{1 a}]^{+}$rendered with $\mathrm{PLATON}^{29}$ and with thermal ellipsoids at the $50 \%$ probability level. Hydrogen atoms and one $\mathrm{SbF}_{6}{ }^{-}$counteranion are omitted for clarity. (C) General scheme for peptide arylation reactions using $[\mathbf{1 a - c}]^{+}$. (D) LC trace of purified S-( $p$-ethylbenzene) GSH conjugate.

With complexes [1a-c] $\left[\mathrm{SbF}_{6}\right]$ in hand, we next explored their suitability to serve as cysteine arylation reagents. We began our investigation using L-glutathione (GSH) as a model peptide substrate and employed our previously developed Au(III)-mediated cysteine arylation reaction conditions. ${ }^{18}$ Quantitative conversion to the corresponding $S$-aryl bioconjugates was observed upon treatment of GSH with [1a-c] $\left[\mathrm{SbF}_{6}\right]$ (3 equiv) at ambient temperature in TRIS ((tris(hydroxymethyl)aminomethane), $\mathrm{pH}$ 7)-buffered solutions of 70:30 $\mathrm{H}_{2} \mathrm{O}: \mathrm{MeCN}(\mathrm{v} / \mathrm{v})$ within minutes (Figure 2C) as assayed by LC-MS analyses of the crude reaction mixtures. The products were purified by reversedphase HPLC (Figure 2D shows a representative LC trace of purified $p$-ethylbenzene conjugate), which enabled facile separation of the arylated bioconjugates from $\mathbf{1}$, which is the only observable Au-containing byproduct generated (SI section S3) following arylation. The bioconjugation reactions proceed with nearly quantitative conversion efficiency ( $>99 \%$ ) and with rapid reaction kinetics as assayed by LC-MS analyses of the crude reaction mixtures. The efficiency of these reactions is comparable with that observed for our previously reported Au(III)-mediated cysteine arylation reactions using complexes supported by the related Me-DalPhos ligand, ${ }^{18}$ which led us to perform a comparative kinetic analysis between the two systems. 


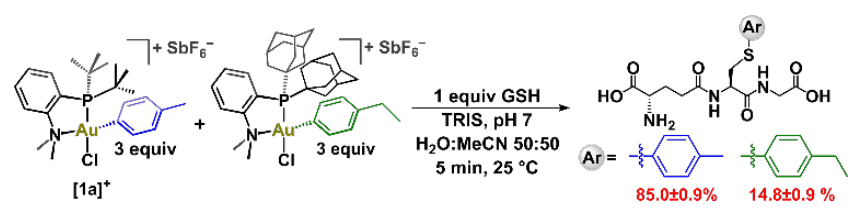

Scheme 1. Competition reaction between $[\mathbf{1} \mathbf{a}]\left[\mathrm{SbF}_{6}\right]$ and [(Me-DalPhos) $\mathrm{Au}(p$-ethylbenzene) $\mathrm{Cl}]\left[\mathrm{SbF}_{6}\right]$ with L-glutathione (GSH).

We performed two sets of cysteine-arylation competition reactions using the tolyl and $p$-ethylbenzene derivatives of both (P,N)-supported Au(III) systems on account of the similar electronic and steric profile of the aryl substituents. For each experiment, glutathione was treated with equimolar mixtures of either $[\mathbf{1 a}]\left[\mathrm{SbF}_{6}\right]$ and [(Me-DalPhos)Au(p-ethylbenzene)Cl] $\left.\mathrm{SbF}_{6}\right]$, or $[\mathbf{1} \mathbf{b}]\left[\mathrm{SbF}_{6}\right]$ and [(Me-DalPhos)Au(tolyl)Cl][SbF 6 (Scheme 1) under conditions compatible with both systems, and the product selectivity was assessed by LC-MS analysis of the crude reaction mixtures. Analysis of 12 independent reactions indicated that the present tert-butyl-substituted $(\mathrm{P}, \mathrm{N})$ complexes outcompeted the Me-DalPhos derivatives in a nearly 6:1 ratio, suggesting the cysteine arylation reaction kinetics for the present system are on the order of, or faster than the reaction kinetics using our previously reported (Me-DalPhos)Au(III)ArCl reagents $\left(10^{3}-10^{4} \mathrm{M}^{-1} \mathrm{~s}^{-1}\right) \cdot 14,18$

\section{PEPTIDE STAPLING}

To highlight the versatility of the present organometallic platform, we next extended this approach to peptide macrocyclization through the formation of intramolecular aryl-bridged cysteine linkages. Peptide stapling has emerged as an attractive strategy for developing state-of-the-art therapeutic agents as stapled peptides have been shown to display favorable properties when compared with those of their linear counterparts such as enhanced cell permeability and higher resistance towards proteolytic degradation. ${ }^{30-38}$ There is, however, a need to expand the synthetic repertoire of readily accessible peptide stapling techniques that allow for systematic and modular tuning of the "staple" linkage. 39,40

Here, we have expanded upon our recently demonstrated method of $\mathrm{Au}(\mathrm{III})$-mediated peptide stapling by employing two different aryl-bridged dinuclear Au(III) complexes with organic linkers of varying length. The parasubstituted phenylene $\left([\mathbf{2 a}]\left[\mathrm{SbF}_{6}\right]_{2}\right)$ and biphenyl-bridged $\left([\mathbf{2 b}]\left[\mathrm{SbF}_{6}\right]_{2}\right)$ bimetallic stapling reagents were prepared following the synthetic procedure shown in Figure 3A. Treatment of the parent diiodo arene with $\mathbf{1}$ (2 equiv) in the presence of $\mathrm{AgSbF}_{6}$ (2 equiv) resulted in clean conversion to the corresponding dicationic bimetallic complexes as evidenced by the single resonance observed in the ${ }^{31} \mathrm{P}$ NMR spectrum of each isolated product. Both air-stable salts were structurally characterized after isolation of single, Xray quality crystals, and the solid-state structures of the cations are displayed in Figure 3B. While [2a] ${ }^{2+}$ adopts a cis orientation of the $(\mathrm{P}, \mathrm{N})$ ligands, a trans configuration is observed in biphenyl-bridged $[\mathbf{2 b}]^{2+}$. However, the presence of a single resonance in the ${ }^{31} \mathrm{P}$ NMR spectrum of $[\mathbf{2 b}]^{2+}$ can be ascribed to rapid rotation of the $(\mathrm{P}, \mathrm{N}) \mathrm{Au}\left(\mathrm{C}_{6} \mathrm{H}_{4}\right) \mathrm{Cl}$ units about the biphenyl $\mathrm{C}-\mathrm{C}$ single bond on the NMR time scale in solution $\left(25^{\circ} \mathrm{C}\right)$. This resonance is therefore represented as a weighted average and suggests that the trans ligand geometry of $[\mathbf{2 b}]^{2+}$ is only locked in place in the solid state.

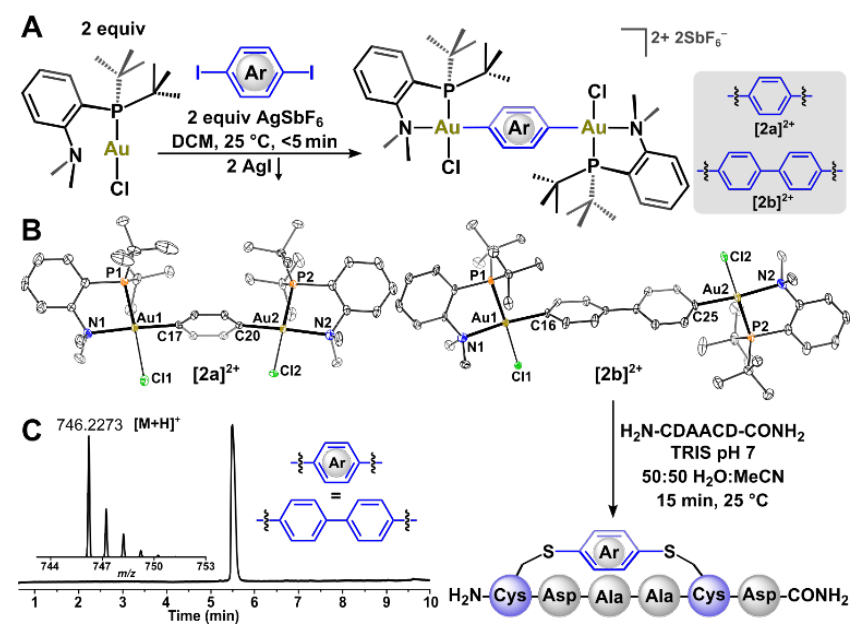

Figure 3. (A) Synthetic scheme for the preparation of $p$-phenylene $\left([\mathbf{2 a}]\left[\mathrm{SbF}_{6}\right]_{2}\right)$ and biphenyl-bridged $\left([\mathbf{2} \mathbf{b}]\left[\mathrm{SbF}_{6}\right]_{2}\right)$ bimetallic $\mathrm{Au}(\mathrm{III})$ stapling reagents. (B) Solid-state structure of $[\mathbf{2 a}]^{2+}$ and $[\mathbf{2 b}]^{2+}$ rendered with PLATON ${ }^{29}$ and with thermal ellipsoids at the $50 \%$ probability level. Hydrogen atoms and $\mathrm{SbF}_{6}{ }^{-}$counteranions are omitted for clarity. (C) General procedure for stapling dicysteine peptide, CDAACD, with $[\mathbf{2 a}]\left[\mathrm{SbF}_{6}\right]_{2}$ or $[\mathbf{2} \mathbf{b}]\left[\mathrm{SbF}_{6}\right]_{2}$, and LC trace of purified biphenyl-stapled conjugate.

Complexes $[\mathbf{2 a}]^{2+}$ and $[\mathbf{2 b}]^{2+}$ were used to staple a model di-cysteine peptide, $\mathrm{H}_{2} \mathrm{~N}-\mathrm{CDAACD}-\mathrm{CONH}_{2}$, which bears cysteine residues at the $i, i+4$ positions. The stapling reactions were conducted through treatment of $\mathrm{H}_{2} \mathrm{~N}-\mathrm{CDAACD}-\mathrm{CONH}_{2}$ with a stoichiometric amount of either $[\mathbf{2 a}]\left[\mathrm{SbF}_{6}\right]_{2}$ or $[\mathbf{2} \mathbf{b}]\left[\mathrm{SbF}_{6}\right]_{2}$ in TRISbuffered solutions of 50:50 $\mathrm{H}_{2} \mathrm{O}: \mathrm{MeCN}$ (v/v) (Figure $3 \mathrm{C}$ ). The macrocyclization reactions were judged complete after analysis of the crude reaction mixtures by LC-MS, which revealed complete consumption of the parent peptide, and formation of the aryl-stapled bioconjugate. The $p$-phenylene and biphenyl-stapled peptides were purified away from the $\mathbf{1}$ byproduct by reversed-phase HPLC, and the LC trace of the purified biphenyl-stapled conjugate is shown in Figure 3C. The present chemistry provides a straightforward approach to peptide macrocyclization and offers facile access to a potential library of air-stable stapling reagents of varying length, size, and rigidity that can easily be prepared in one synthetic step. 


\section{PEPTIDE BICYCLE SYNTHESIS}

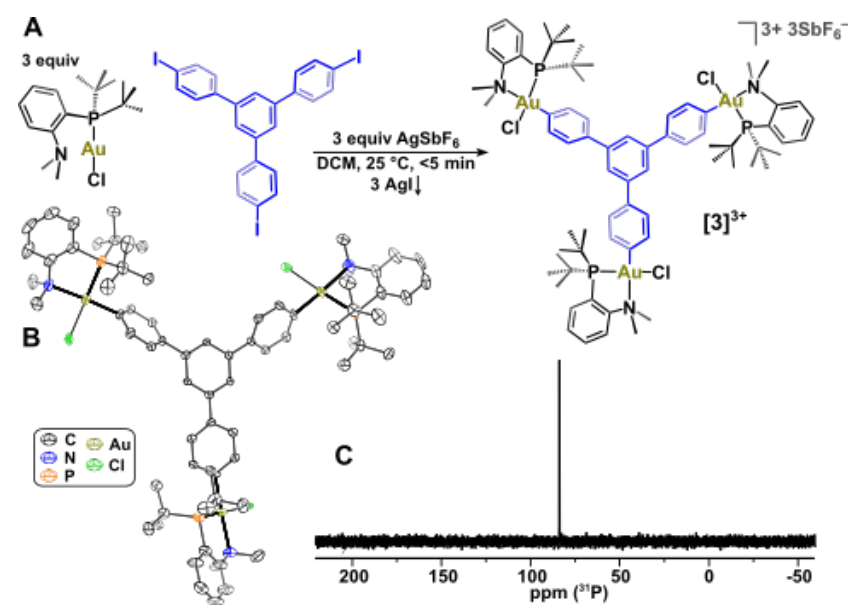

Figure 4. (A) Synthetic protocol for the preparation of $[3]\left[\mathrm{SbF}_{6}\right]_{3}$. (B) Solid-state structure of [3] ${ }^{3+}$ rendered with PLATON29 with thermal ellipsoids at the $50 \%$ probability level and with hydrogen atoms, three $\mathrm{SbF}_{6}$ - counteranions and disorder removed for clarity. (C) ${ }^{31} \mathrm{P}\left\{{ }^{1} \mathrm{H}\right\}$ NMR spectrum of $[3]\left[\mathrm{SbF}_{6}\right]_{3}$ (DMSO- $d_{6}, 162 \mathrm{MHz}$, $\left.25^{\circ} \mathrm{C}\right)$.

Encouraged by the straightforward multi-metalation procedures described (vide supra), we envisioned that access to a trimetallic Au(III) complex would provide a new entry point to the assembly of peptide macrocycles of higher structural complexity. Structure-driven design of abiotic peptide-based molecules plays an integral role in drug discovery, with applications ranging from the advancement of antiviral ${ }^{41}$ and antitumor ${ }^{42,43}$ agents to the development of drug therapeutics that are capable of mimicking or disrupting specific protein-protein interactions. ${ }^{44}$ In order to adequately mimic protein function, however, complex structural topologies are often required for peptidebased therapeutics. This need has thereby driven research efforts towards developing highly-efficient and versatile synthetic strategies of building protein-like bioactive conformations (strands, helices, turns) through peptide cyclization in conjunction with the use of molecular constraints. ${ }^{45,46}$ With this in mind, we were specifically interested in applying the present $\mathrm{Au}(\mathrm{III})$ mediated bioconjugation strategy to the synthesis of bicyclic peptides on account of the rapidly developing interest in their ability to serve as next-generation therapeutic agents. ${ }^{47-50}$

Following a metalation procedure similar to those previously described (vide supra), we prepared the trimetallic $(\mathrm{P}, \mathrm{N})$-supported $\mathrm{Au}(\mathrm{III})$ complex, $[3]^{3+}$, in which three meta-substituted $(\mathrm{P}, \mathrm{N}) \mathrm{Au}\left(\mathrm{C}_{6} \mathrm{H}_{4}\right) \mathrm{Cl}$ fragments flank a central aryl anchor. Treatment of 1,3,5-tris(4iodophenyl)benzene with 1 (3 equiv) in the presence of $\mathrm{AgSbF}_{6}$ (3 equiv) in $\mathrm{CH}_{2} \mathrm{Cl}_{2}$ resulted in clean conversion to $[3]^{3+}$ (Figure 4A) at ambient temperature as assessed by ${ }^{31} \mathrm{P}$, and ${ }^{1} \mathrm{H}$ NMR spectroscopic analysis of the product after workup. Complex [3][SbF$]_{3}$ displays a single resonance in its ${ }^{31} \mathrm{P}\left\{{ }^{1} \mathrm{H}\right\}$ NMR spectrum ( $\delta 83.8 \mathrm{ppm}$, Figure $\left.4 \mathrm{C}\right)$, which is consistent with the formation of a three-fold symmetric complex in which full, tri-metalation was achieved. An X-ray diffraction analysis conducted on a single crystal of $[3]\left[\mathrm{SbF}_{6}\right]_{3}$ confirmed its identity as the $C_{3}$-symmetric trimetallic complex, and the solid-state structure is displayed in Figure 4B.

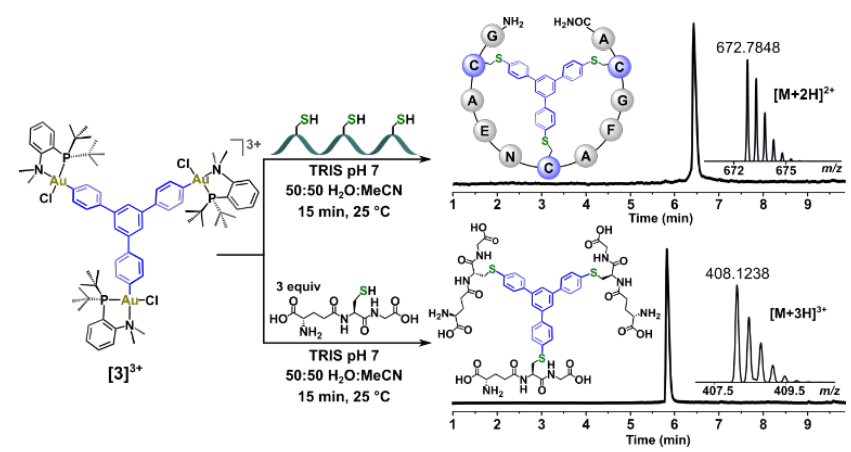

Figure 5. (Top) Treatment of tricysteine peptide, $\mathrm{H}_{2} \mathrm{~N}-$ GCAENCAFGCA-CONH 2 , with [3][ $\left.\mathrm{SbF}_{6}\right]_{3}$ to yield the bicyclic peptide, with LC-MS characterization data of the purified product. (Bottom) Multi-site peptide conjugation through treatment of $[3]\left[\mathrm{SbF}_{6}\right]_{3}$ with GSH (3 equiv), with LC-MS characterization data of the purified conjugate.

Efficient cyclization of the model, linear tricysteine peptide, $\mathrm{H}_{2} \mathrm{~N}$-GCAENCAFGCA-CONH $\mathrm{H}_{2}$, via the three cysteine thiols was established through its treatment with complex [3] ${ }^{3+}$ in a TRIS-buffered 50:50 $\mathrm{H}_{2} \mathrm{O}: \mathrm{MeCN}(\mathrm{v} / \mathrm{v})$ solvent mixture (Figure 5 top). Analysis of the crude reaction mixture by LC-MS indicated complete conversion to the bicyclic peptide, and no Au-containing partiallycyclized adducts were detected. The entropically-favored intramolecular cyclization combined with the highly thiophilic nature of the $\mathrm{Au}(\mathrm{III})$ centers likely contribute to the exceptionally efficient and rapid formation of the peptide bicycle. ${ }^{51,52}$ The tetraaryl-anchored bicycle peptide was purified by reversed-phase HPLC, and the LC trace and corresponding ESI-MS(+) data of the isolated conjugate are shown in Figure 5 (top). This experiment showcases how an organometallic reagent can be used for bicycle peptide formation, and diversifies the repertoire of metal-mediated methods of peptide macrocyclization..$^{53}$ Importantly, this straightforward and synthetically facile one-step peptide cyclization method offers the potential to serve as a general approach to the systematic assembly of larger and structurally diverse peptide bicycle libraries and provides a versatile tool relevant to applications in chemical biology and peptide-based drug discovery.

\section{MULTI-SITE PEPTIDE CONJUGATION}

We next leveraged this trimetallic platform to build well-defined, peptide-based molecular systems of higher structural complexity through the reaction between each of the three Au(III) centers of complex [3 $]^{3+}$ with the cysteine residue of three independent peptide substrates. This multi-site peptide bioconjugation was 
established through treatment of [3] $]^{3+}$ with excess glutathione following synthetic and purification procedures adapted from those described earlier in this work (vide supra) and the LC-MS data of the purified bioconjugate are displayed in Figure 5 (bottom). This multipeptide branched hybrid molecular species is reminiscent of the architectures of polypeptide-based dendrimers, which have received widespread attention for their use in diagnostic, therapeutic, and prophylactic applications, among others, on account of their well-defined size, multivalency and chemical composition. ${ }^{54-60}$ This facile organometallic-based synthetic strategy has the potential to both diversify the approach to building peptide-based dendrimers, and to improve upon the accessibility of highly complex architectures while circumventing some of the synthetic challenges associated with assembling exceptionally intricate supramolecular hybrid systems. ${ }^{59,60}$

\section{D-HYBRID NANOCLUSTER ASSEMBLY}

We further extended the Au(III)-mediated synthesis of multivalent molecular systems to the assembly of more complex, three-dimensional hybrid nanoparticles that are based on robust boron cluster building blocks. Through functionalization of each boron vertex of an icosahedral $\mathrm{B}_{12}$ core with organometallic $(\mathrm{P}, \mathrm{N}) \mathrm{Au}(\mathrm{III}) \mathrm{ArCl}$ fragments, the boron-cluster-based approach to the synthesis of multivalent clusters provides a systematic method of preparing biologicallyrelevant hybrid nanoassemblies through $\mathrm{Au}(\mathrm{III})$ mediated $\mathrm{C}-\mathrm{S}$ bond-forming conjugation reactions. We have previously shown that dodecaborate clusters perfunctionalized with biologically-relevant thiolate surface ligands (saccharides, peptides, poly(ethyleneglycol) polymers) exhibit high structural stability under biologically-relevant conditions due to their full covalency, which consequently provided an appropriate platform for us to interrogate their multivalent binding interactions with complex protein targets. ${ }^{28,61-63}$ While many other nanoscale assemblies display multivalent binding capabilities, such systems are seldom atomically precise, ${ }^{64-69}$ which has driven research efforts focused on developing versatile assembly processes that provide access to well-defined and programmable systems. With a constantly evolving field of nanobiotechnology dedicated to addressing these challenges, we were motivated to expand upon the synthetic capabilities and utility of the boron-cluster-based platform by employing the present $(\mathrm{P}, \mathrm{N}) \mathrm{Au}(\mathrm{III})$-mediated conjugation strategy to assemble atomically-precise, robust hybrid nanoclusters with multivalent binding capabilities.

We adapted the straightforward procedures described for the preparation of the mono-, bi-, and trimetallic systems $\left([\mathbf{1 a}-\mathbf{c}]^{+},[\mathbf{2 a}, \mathbf{b}]^{2+},[\mathbf{3}]^{3+}\right)$, and applied a similar synthetic approach to the more complex boron cluster platform, in which simultaneous and efficient metalation at all twelve vertices of the $B_{12}$ cluster is required for successful preparation of the desired permetalated $\mathrm{Au}(\mathrm{III})$ synthon. Accordingly, under open-atmosphere conditions, treatment of the previously reported per-4-iodobenzyloxy-substituted $\mathrm{B}_{12}$ cluster, $\mathrm{B}_{12}\left(\mathrm{OCH}_{2} \mathrm{C}_{6} \mathrm{H}_{4} \mathrm{I}\right)_{12}{ }^{28}$ with excess 1 in the presence of $\mathrm{AgSbF}_{6}$ in refluxing $\mathrm{CH}_{2} \mathrm{Cl}_{2}$ (Figure $6 \mathrm{~A}$ ) resulted in the formation of one clean species after workup as assessed by the presence of a single resonance in the ${ }^{31} \mathrm{P}$ NMR spectrum that is shifted by ca. $30 \mathrm{ppm}$ downfield from that of the 1 precursor (Figure 6B). The location of this signal falls within the ${ }^{31} \mathrm{P}$ NMR region that is diagnostic for the square planar (P,N)Au(III)ArCl complexes reported in this work, and is consistent with successful oxidative addition of $\mathrm{Au}(\mathrm{I})$ across all 12 peripheral $\mathrm{C}-\mathrm{I}$ bonds of the $\mathrm{B}_{12}\left(\mathrm{OCH}_{2} \mathrm{C}_{6} \mathrm{H}_{4} \mathrm{I}\right)_{12}$ cluster, and formation of the $\left[\mathrm{B}_{12}\left(\mathrm{OCH}_{2} \mathrm{C}_{6} \mathrm{H}_{4}-(\mathrm{P}, \mathrm{N}) \mathrm{AuCl}\right)_{12}\right]\left[\mathrm{SbF}_{6}\right]_{11}$ ([4][SbF 6$]_{11}$ ) product.

The UV-vis spectrum of the purple-red [4] $\left[\mathrm{SbF}_{6}\right]_{11}$ salt displays two major absorptions located at $\lambda_{\max } 340$ and $550 \mathrm{~nm}$, respectively (Figure 6C). The $340 \mathrm{~nm}$ transition is attributed to ligand-based charge transfer, while the absorption located at $550 \mathrm{~nm}$ is diagnostic of hypocloso- $\mathrm{B}_{12}$ clusters in the monoanionic charge state. ${ }^{62,70-72}$ The presence of this absorption in addition to the silent ${ }^{11} \mathrm{~B}$ NMR spectrum of purified $[4]\left[\mathrm{SbF}_{6}\right]_{11}$ (SI Section 2.1.8.) suggests that the $B_{12}$

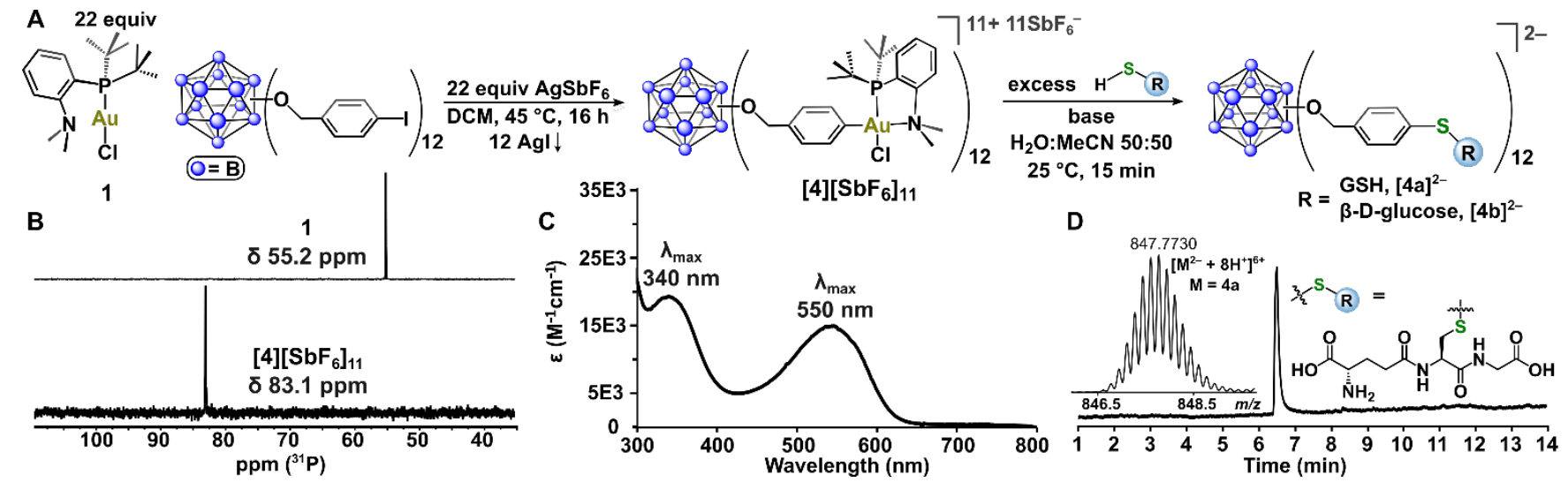

Figure 6. (A) Synthetic scheme for the preparation of [4] $\left[\mathrm{SbF}_{6}\right]_{11}$ and conditions for subsequent reactions with thiol-based nucleophiles to afford the GSH ([4a $\left.]^{2-}\right)$ and 1-thioglucose $\left([\mathbf{4 b}]^{2-}\right)$ conjugates. (B) ${ }^{31} \mathrm{P}\left\{{ }^{1} \mathrm{H}\right\}$ NMR spectra of $\mathbf{1}$ and [4] [SbF $]_{11}\left(162 \mathrm{MHz}, 25^{\circ} \mathrm{C}\right)$. (C) UV-vis spectrum of [4] [SbF 6$]_{11}$ $\left(0.1 \mathrm{mM}, \mathrm{MeCN}, 25^{\circ} \mathrm{C}\right)$. (D) LC-MS data of purified GSH cluster conjugate, [4a] ${ }^{2-}$. 
cluster underwent single-electron reduction during the synthetic procedure. It is well documented that perfunctionalized $\mathrm{B}_{12}$ clusters undergo rich redox chemistry, ${ }^{62,70-74}$ and this redox behavior is consistent with the chemistry observed during the preparation of the analogous $\left[\mathrm{B}_{12}\left(\mathrm{OCH}_{2} \mathrm{C}_{6} \mathrm{H}_{4}(\mathrm{Me}-\mathrm{DalPhos}) \mathrm{AuCl}\right)_{12}\right]^{11+}$ cluster we have previously reported and likely due to a solvent-based electron transfer process (See SI Section S2.1.8.). ${ }^{28}$ It is noted that the one-electron reduction of the $\mathrm{B}_{12}$ core results in an overall $11+$ charge for $[4]^{11+}$ as opposed to the $12+$ charge that would be expected in the absence of any cluster-based redox.

Having successfully functionalized the surface of the $\mathrm{B}_{12}$ core with a dense layer of organometallic synthetic handles, we next probed this system for its ability to serve as a building block for the assembly of atomically-precise hybrid nanoclusters bearing biologicallyrelevant groups. Peptide (GSH) and saccharide-based ( $\beta$-D-thioglucose) substrates bearing nucleophilic thiol centers were employed as bioconjugation partners to showcase the chemoselectivity and versatility of the present assembly approach. Treatment of in-situ-generated $[4]\left[\mathrm{SbF}_{6}\right]_{11}$ with GSH in a TRIS-buffered DMF: $\mathrm{H}_{2} \mathrm{O}(50: 50 \mathrm{v} / \mathrm{v})$ solution resulted in a gradual color change from dark purple to colorless over the course of $15 \mathrm{~min}$, which is indicative of a single-electron reduction of the cluster core from the radical monoanionic to the diamagnetic, dianionic charge state. Cluster reduction has been previously observed during thiol conjugation reactions of similar systems, and is consistent with the reducing capacity of thiolate species. $^{28,61,63}$ Conversion of [4] ${ }^{11+}$ to the twelve-fold-substituted GSH bioconjugate $\left([\mathbf{4 a}]^{2-}\right)$ was assessed by LCMS analysis of the reaction mixture. The crude product was purified by reversed-phase HPLC, and the LC-MS data confirming the purity and identity of the resulting bioconjugate are displayed in Figure 6D.

We next focused our attention on the preparation of a boron cluster bearing a dense surface layer of carbohydrate recognition groups. There is significant interest in developing synthetic approaches for the systematic assembly of well-defined saccharide-grafted nanostructures due to the potential for these systems to engage in, disrupt, or mimic multivalent protein-glycan recognition processes in biological systems. ${ }^{75-79}$ Many of these multivalent interactions play vital roles in biological processes such as those involving pathogen-host relationships, which makes the design of synthetic species with precisely engineered spatial and topological ligand morphologies critical to understanding structure-function relationships that dictate the binding between abiotic nanoassemblies and their complex biological targets. To demonstrate this synthetic approach, we treated in-situgenerated [4] $\left[\mathrm{SbF}_{6}\right]_{11}$ with excess $[\mathrm{Na}][1-$ thio- $\beta$-D-glucose] in a $\mathrm{H}_{2} \mathrm{O}$ :DMF $(50: 50, \mathrm{v} / \mathrm{v})$ mixture, which resulted in saccharide conjugation at every boron vertex, concomitant with one-electron cluster reduction to result in the formation of the glucose-grafted nanocluster ([Na $\left.]_{2}[4 \mathbf{b}]\right)$.
The water-soluble product was purified by size-exclusion chromatography, which afforded the cluster conjugate as an air-stable solid that was characterized by ${ }^{11} \mathrm{~B}$ and ${ }^{1} \mathrm{H}$ NMR spectroscopy (SI Section S2.3.7.), and ESI-MS(-). The present work serves as an important proof-of-principle demonstration that the densely functionalized, organometallic [4] ${ }^{11+}$ cluster can serve as a competent synthon for the preparation of highly complex, yet welldefined hybrid nanoassemblies, and provides a versatile strategy for the synthesis of new, biocompatible multivalent systems. ${ }^{28,61,65,76,80-82}$

\section{CONCLUSION}

Here, we have introduced an organometallic synthetic platform based on robust aminophosphinesupported $\mathrm{Au}(\mathrm{III})$ complexes that demonstrate efficient and selective cysteine S-arylation of bimoleucle substrates. We report the synthesis and characterization of mono, bi, tri, and dodecametallic complexes that provide access to a rage of arylated bioconjugates including stapled peptides, a macrocyclic peptide bicycle, a small dendrimer, and a peptide-grafted hybrid inorganic cluster. This work highlights how tailored inorganic and organometallic reagents can be leveraged for site specific modifications of biomolecules ${ }^{6,7,10,83 \mathrm{a}-\mathrm{f}}$ and offers an efficient and versatile approach to bioconjugation.

\section{ASSOCIATED CONTENT}

Crystallographic data are available from the Cambridge Crystallographic Data Centre, under reference numbers CCDC 2050323-2050328.

\section{AUTHOR INFORMATION \\ Corresponding Authors}

Alexander M. Spokoyny - Department of Chemistry and Biochemistry, University of California, Los Angeles, 607 Charles E. Young Dr. E., Los Angeles, CA 90095; California NanoSystems Institute, University of California, Los Angeles 570 Westwood Plaza, Los Angeles, CA 90095; orcid.org/0000-0002-5683-6240

Email:spokoyny@chem.ucla.edu

Julia M. Stauber - Department of Chemistry and Biochemistry, University of California, Los Angeles, 607 Charles E. Young Dr. E., Los Angeles, CA 90095; Department of Chemistry and Biochemistry, University of California, San Diego, 9500 Gilman Dr., La Jolla, CA 92092; orcid.org/0000-0001-9783-907X

Email: jstauber@ucla.edu

\section{Author}

Arnold L. Rheingold - Department of Chemistry and Biochemistry, University of California, San Diego, 9500 Gilman Dr., La Jolla, CA 92092; orcid.org/0000-0003-4472-8127

\section{NOTES}

UCLA has patents on several compounds reported in this work from which A.M.S. and current/former co-workers may receive royalty payments. The $\mathrm{Cs}_{2}\left[\mathrm{~B}_{12}(\mathrm{OH})_{12}\right]$ salt (Catalog \#902209) is commercially available through the MilliporeSigma catalog. 


\section{ACKNOWLEDGMENTS}

This work was supported by the National Institutes of Health (NIH) Maximizing Investigators Research Award (MIRA, R35GM124746). A. M. S. is a Research Corporation for Science Advancement (RCSA) Cottrell Scholar and a Dreyfus Foundation Camille Dreyfus Teacher-Scholar.

\section{REFERENCES}

(1) Boutureira, 0.; Bernardes, G. J. L. Advances in Chemical Protein Modification. Chem. Rev. 2015, 115, 2174-2195.

(2) Bernardes, G. J. L.; Chalker, J. M.; Davis, B. G. Chemical Protein Modification; Pignataro, B., Ed.; Wiley, 2010.

(3) Agarwal, P.; Bertozzi, C. R. Site-Specific AntibodyDrug Conjugates: The Nexus of Bioorthogonal Chemistry, Protein Engineering, and Drug Development. Bioconjug. Chem. 2015, 26 (2), 176-192.

(4) Witus, L. S.; Francis, M. B. Using Synthetically Modified Proteins to Make New Materials. Acc. Chem. Res. 2011, 44 (9), 774-783.

(5) Chalker, J. M. Metal-Mediated Bioconjugation. In Chemoselective and Bioorthogonal Ligation Reactions. In Chemoselective and Bioorthogonal Ligation Reactions; Algar, W. R., Dawson, P., Medintz, I. L., Eds.; Wiley, 2017; pp 231-270.

(6) Zhang, C.; Vinogradova, E. V.; Spokoyny, A. M.; Buchwald, S. L.; Pentelute, B. L. Arylation Chemistry for Bioconjugation. Angew. Chem. Int. Ed. 2019, 58 (15), 4810-4839.

(7) Ohata, J.; Martin, S. C.; Ball, Z. T. Metal-Mediated Functionalization of Natural Peptides and Proteins: Panning for Bioconjugation Gold. Angew. Chem. Int. Ed. 2019, 58 (19), 6176-6199.

(8) Vinogradova, E. V. Organometallic Chemical Biology: An Organometallic Approach to Bioconjugation. Pure Appl. Chem. 2017, 89 (11), 1619-1640.

(9) Kung, K. K.-Y.; Ko, H.-M.; Cui, J.-F.; Chong, H.-C.; Leung, Y.-C.; Wong, M.-K. Cyclometalated Gold(III) Complexes for Chemoselective Cysteine Modification via Ligand Controlled C-S BondForming Reductive Elimination. Chem. Commun. 2014, 50 (80), 11899-11902.

(10) Willwacher, J.; Raj, R.; Mohammed, S.; Davis, B. G. Selective Metal-Site-Guided Arylation of Proteins. J. Am. Chem. Soc. 2016, 138 (28), 86788681.

(11) Chalker, J. M.; Bernardes, G. J. L.; Lin, Y. A.; Davis, B. G. Chemical Modification of Proteins at Cysteine: Opportunities in Chemistry and Biology. Chem. Asian J. 2009, 4, 630-640.

(12) Gunnoo, S. B.; Madder, A. Chemical Protein Modification through Cysteine. ChemBioChem 2016, 17 (7), 529-553.

(13) Vara, B. A.; Li, X.; Berritt, S.; Petersson, E. J.; Molander, G. A.; Walters, C. R. Scalable
Thioarylation of Unprotected Peptides and Biomolecules Under $\mathrm{Ni} /$ Photoredox Catalysis. Chem. Sci. 2017, 9, 336-344.

(14) Vinogradova, E. V; Zhang, C.; Spokoyny, A. M.; Pentelute, B. L.; Buchwald, S. L. Organometallic Palladium Reagents for Cysteine Bioconjugation. Nature 2015, 526, 687-691.

(15) Hesp, K. D.; Stradiotto, M. Stereo- and Regioselective Gold-Catalyzed Hydroamination of Internal Alkynes with Dialkylamines. J. Am. Chem. Soc. 2010, 132, 18026-18029.

(16) Lundgren, R. J.; Sappong-Kumankumah, A.; Stradiotto, M. A Highly Versatile Catalyst System for the Cross-Coupling of Aryl Chlorides and Amines. Chem. - A Eur. J. 2010, 16 (6), 19831991.

(17) Zeineddine, A.; Estévez, L.; Mallet-Ladeira, S.; Miqueu, K.; Amgoune, A.; Bourissou, D. Rational Development of Catalytic $\mathrm{Au}(\mathrm{I}) / \mathrm{Au}(\mathrm{III})$ Arylation Involving Mild Oxidative Addition of Aryl Halides. Nat. Commun. 2017, 8 (565), 1-8.

(18) Messina, M. S.; Stauber, J. M.; Waddington, M. A.; Rheingold, A. L.; Maynard, H. D.; Spokoyny, A. M. Organometallic Gold(III) Reagents for Cysteine Arylation. J. Am. Chem. Soc. 2018, 140 (23), 70657069.

(19) Lundgren, R. J.; Stradiotto, M. Rapid Ketone Transfer Hydrogenation by Employing Simple, in Situ Prepared Iridium(I) Precatalysts Supported by "Non-N-H" P,N Ligands. Chem. - A Eur. J. 2008, 14 (33), 10388-10395.

(20) Wang, Z.; Wang, Y.; Zhang, L. Soft Propargylic Deprotonation: Designed Ligand Enables AuCatalyzed Isomerization of Alkynes to 1,3-Dienes. J. Am. Chem. Soc. 2014, 136 (25), 8887-8890.

(21) Ji, K.; Zhao, Y.; Zhang, L. Optimizing P,N-Bidentate Ligands for Oxidative Gold Catalysis: Efficient Intermolecular Trapping of $\alpha$-Oxo Gold Carbenes by Carboxylic Acids. Angew. Chem. Int. Ed. 2013, 52 (25), 6508-6512.

(22) Luo, Y.; Ji, K.; Li, Y.; Zhang, L. Tempering the Reactivities of Postulated $\alpha$-Oxo Gold Carbenes Using Bidentate Ligands: Implication of Tricoordinated Gold Intermediates and the Development of an Expedient Bimolecular Assembly of 2,4-Disubstituted Oxazoles. J. Am. Chem. Soc. 2012, 134 (42), 17412-17415.

(23) Herrero-Gómez, E.; Nieto-Oberhuber, C.; López, S.; Benet-Buchholz, J.; Echavarren, A. M. Cationic H1/H2-Gold(I) Complexes of Simple Arenes. Angew. Chem. Int. Ed. 2006, 45 (33), 5455-5459.

(24) Chen, L.; Ren, P.; Carrow, B. P. Tri(1Adamantyl)Phosphine: Expanding the Boundary of Electron-Releasing Character Available to Organophosphorus Compounds. J. Am. Chem. Soc. 2016, 138 (20), 6392-6395.

(25) Touil, M.; Bechem, B.; Hashmi, A. S. K.; Engels, B.; Omary, M. A.; Rabaâ, H. Theoretical Study of Weak CC Double Bond Coordination in a Gold (I) 
Catalyst Precursor. J. Mol. Struct. THEOCHEM 2010, 957 (1-3), 21-25.

(26) Schmidbaur, H.; Brachthauser, B.; Steigelmann, O.; Beruda, H. Preparation and Structure of Hexakis[(Trialkylphosphane)Aurio(I)]Methaniu $\mathrm{m}(2+)$ Salts $\left[(\mathrm{LAu})_{6} \mathrm{C}\right]^{2+}\left(\mathrm{X}^{-}\right)_{2}$ with $\mathrm{L}=\mathrm{Et}_{3} \mathrm{P}, \mathrm{Pr}_{3} \mathrm{P}$ and $\mathrm{X}=\mathrm{BF}_{4}^{-}, \mathrm{B}_{3} \mathrm{O}_{3} \mathrm{~F}_{4}^{-}$. Chem.Ber. 1992, 125 (I), $2705-2710$.

(27) Joost, M.; Zeineddine, A.; Estévez, L.; MalletLadeira, S.; Miqueu, K.; Amgoune, A.; Bourissou, D. Facile Oxidative Addition of Aryl Iodides to Gold(I) by Ligand Design: Bending Turns on Reactivity. J. Am. Chem. Soc. 2014, 136, 1465414657.

(28) Stauber, J. M.; Qian, E. A.; Han, Y.; Rheingold, A. L.; Král, P.; Fujita, D.; Spokoyny, A. M. An Organometallic Strategy for Assembling Atomically Precise Hybrid Nanomaterials. J. Am. Chem. Soc. 2020, 142 (1), 327-334.

(29) Spek, A. L. Structure Validation in Chemical Crystallography. Acta Crystallogr. Sect. D 2009, 65, 148-155.

(30) Spokoyny, A. M.; Zou, Y.; Ling, J. J.; Yu, H.; Lin, Y. S.; Pentelute, B. L. A Perfluoroaryl-Cysteine SNAr Chemistry Approach to Unprotected Peptide Stapling. J. Am. Chem. Soc. 2013, 135, 5946-5949.

(31) Lautrette, G.; Touti, F.; Lee, H. G.; Dai, P.; Pentelute, B. L. Nitrogen Arylation for Macrocyclization of Unprotected Peptides. J. Am. Chem. Soc. 2016, 138 (27), 8340-8343.

(32) Lau, Y. H.; de Andrade, P.; Quah, S.-T.; Rossmann, M.; Laraia, L.; Sköld, N.; Sum, T. J.; Rowling, P. J. E.; Joseph, T. L.; Verma, C.; Hyvönen, M.; Itzhaki, L. S.; Venkitaraman, A. R.; Brown, C. J.; Lane, D. P.; Spring, D. R. Functionalised Staple Linkages for Modulating the Cellular Activity of Stapled Peptides. Chem. Sci. 2014, 5 (5), 1804-1809.

(33) Bernardim, B.; Cal, P. M. S. D.; Matos, M. J.; Oliveira, B. L.; Martínez-Sáez, N.; Albuquerque, I. S.; Perkins, E.; Corzana, F.; Burtoloso, A. C. B.; Jiménez-Osés, G.; Bernardes, G. J. L. Stoichiometric and Irreversible CysteineSelective Protein Modification Using Carbonylacrylic Reagents. Nat. Commun. 2016, 7 (May), 13128.

(34) White, C. J.; Yudin, A. K. Contemporary Strategies for Peptide Macrocyclization. Nat. Chem. 2011, 3, 509-524.

(35) Muppidi, A.; Zou, H.; Yang, P. Y.; Chao, E.; Sherwood, L.; Nunez, V.; Woods, A. K.; Schultz, P. G.; Lin, Q.; Shen, W. Design of Potent and Proteolytically Stable Oxyntomodulin Analogs. ACS Chem. Biol. 2016, 11 (2), 324-328.

(36) Kalhor-Monfared, S.; Jafari, M. R.; Patterson, J. T.; Kitov, P. I.; Dwyer, J. J.; Nuss, J. M.; Derda, R. Rapid Biocompatible Macrocyclization of Peptides with Decafluoro-Diphenylsulfone. Chem. Sci. 2016, 7 (6), 3785-3790.

(37) Baek, S.; Kutchukian, P. S.; Verdine, G. L.; Huber,
R.; Holak, T. A.; Lee, K. W.; Popowicz, G. M. Structure of the Stapled P53 Peptide Bound to Mdm2. J. Am. Chem. Soc. 2012, 134 (1), 103-106.

(38) Lau, Y. H.; de Andrade, P.; Wu, Y.; Spring, D. R. Peptide Stapling Techniques Based on Different Macrocyclisation Chemistries. Chem. Soc. Rev. 2015, 44, 91-102.

(39) Yudin, A. K. Macrocycles: Lessons from the Distant Past, Recent Developments, and Future Directions. Chem. Sci. 2015, 6, 30-49.

(40) Verdine, G. L.; Hilinski, G. J. Stapled Peptides for Intracellular Drug Targets, 1st ed.; Elsevier Inc., 2012; Vol. 503.

(41) Meloen, R. H.; Casal, J. I.; Dalsgaard, K.; Langeveld, J. P. M. Synthetic Peptide Vaccines: Success at Last. Vaccine 1995, 13 (10), 885-886.

(42) Marqus, S.; Pirogova, E.; Piva, T. J. Evaluation of the Use of Therapeutic Peptides for Cancer Treatment. J. Biomed. Sci. 2017, 24 (1), 1-15.

(43) Moulton, H. M.; Yoshihara, P. H.; Mason, D. H.; Iversen, P. L.; Triozzi, P. L. Active Specific Immunotherapy with a $\beta$-Human Chorionic Gonadotropin Peptide Vaccine in Patients with Metastatic Colorectal Cancer: Antibody Response Is Associated with Improved Survival. Clin. Cancer Res. 2002, 8 (7), 2044-2051.

(44) Lau, J. L.; Dunn, M. K. Therapeutic Peptides: Historical Perspectives, Current Development Trends, and Future Directions. Bioorganic Med. Chem. 2018, 26 (10), 2700-2707.

(45) Timmerman, P.; Beld, J.; Puijk, W. C.; Meloen, R. H. Rapid and Quantitative Cyclization of Multiple Peptide Loops onto Synthetic Scaffolds for Structural Mimicry of Protein Surfaces. ChemBioChem 2005, 6 (5), 821-824.

(46) Hill, T. A.; Shepherd, N. E.; Diness, F.; Fairlie, D. P. Constraining Cyclic Peptides to Mimic Protein Structure Motifs. Angew. Chem. Int. Ed. 2014, 53 (48), 13020-13041.

(47) Deyle, K.; Kong, X. D.; Heinis, C. Phage Selection of Cyclic Peptides for Application in Research and Drug Development. Acc. Chem. Res. 2017, 50 (8), 1866-1874.

(48) Rhodes, C. A.; Pei, D. Bicyclic Peptides as NextGeneration Therapeutics. Chem. - A Eur. J. 2017, 23 (52), 12690-12703.

(49) Lian, W.; Jiang, B.; Qian, Z.; Pei, D. Cell-Permeable Bicyclic Peptide Inhibitors against Intracellular Proteins. J. Am. Chem. Soc. 2014, 136 (28), 98309833.

(50) Heinis, C.; Rutherford, T.; Freund, S.; Winter, G. Phage-Encoded Combinatorial Chemical Libraries Based on Bicyclic Peptides. Nat. Chem. Biol. 2009, 5 (7), 502-507.

(51) Zou, T.; Lum, C. T.; Lok, C.-N.; Zhang, J.-J.; Che, C.M. Chemical Biology of Anticancer Gold(III) and Gold(I) Complexes. Chem. Soc. Rev. 2015, 44, 8786-8801.

(52) On-Yee Chan, A.; Lui-Lui Tsai, J.; Kar-Yan Lo, V.; Li, 
G.-L.; Wong, M.-K.; Che, C.-M. Gold-Mediated Selective Cysteine Modification of Peptides Using Allenes. Chem. Commun. 2013, 49 (14), 1428-

(53) Rivera, D. G.; Ojeda-Carralero, G. M.; Reguera, L.; Van Der Eycken, E. V. Peptide Macrocyclization by Transition Metal Catalysis. Chem. Soc. Rev. 2020, 49 (7), 2039-2059.

(54) Sadler, K.; Tam, J. P. Peptide Dendrimers: Applications and Synthesis. Rev. Mol. Biotechnol. 2002, 90 (3-4), 195-229.

(55) Tabatabaei Mirakabad, F. S.; Khoramgah, M. S.; Keshavarz F., K.; Tabarzad, M.; Ranjbari, J. Peptide Dendrimers as Valuable Biomaterials in Medical Sciences. Life Sci. 2019, 233 (May), 116754.

(56) Mignani, S.; El Kazzouli, S.; Bousmina, M. M.; Majoral, J. P. Dendrimer Space Exploration: An Assessment of Dendrimers/Dendritic Scaffolding as Inhibitors of Protein-Protein Interactions, a Potential New Area of Pharmaceutical Development. Chem. Rev. 2014, 114 (2), 13271342.

(57) Mintzer, M. A.; Dane, E. L.; O’Toole, G. A.; Grinstaff, M. W. Exploiting Dendrimer Multivalency to Combat Emerging and Re-Emerging Infectious Diseases. Mol. Pharm. 2012, 9 (3), 342-354.

(58) Liu, J.; Gray, W. D.; Davis, M. E.; Luo, Y. Peptideand Saccharide-Conjugated Dendrimers for Targeted Drug Delivery: A Concise Review. Interface Focus 2012, 2 (3), 307-324.

(59) Crespo, L.; Sanclimens, G.; Pons, M.; Giralt, E.; Royo, M.; Albericio, F. Peptide and Amide BondContaining Dendrimers. Chem. Rev. 2005, 105 (5), 1663-1681.

(60) Joshi, V. G.; Dighe, V. D.; Thakuria, D.; Malik, Y. S.; Kumar, S. Multiple Antigenic Peptide (MAP): A Synthetic Peptide Dendrimer for Diagnostic, Antiviral and Vaccine Strategies for Emerging and Re-Emerging Viral Diseases. Indian J. Virol. 2013, 24 (3), 312-320.

(61) Qian, E. A.; Wixtrom, A. I.; Axtell, J. C.; Saebi, A.; Jung, D.; Rehak, P.; Han, Y.; Moully, E. H.; Mosallaei, D.; Chow, S.; Messina, M. S.; Wang, J. Y.; Royappa, A. T.; Rheingold, A. L.; Maynard, H. D.; Král, P.; Spokoyny, A. M. Atomically Precise Organomimetic Cluster Nanomolecules Assembled via Perfluoroaryl-Thiol $\mathrm{S}_{\mathrm{N}} \mathrm{Ar}$ Chemistry. Nat. Chem. 2017, 9 (4), 333-340.

(62) Axtell, J. C.; Saleh, L. M. A.; Qian, E. A.; Wixtrom, A. I.; Spokoyny, A. M. Synthesis and Applications of Perfunctionalized Boron Clusters. Inorg. Chem. 2018, 57 (5), 2333-2350.

(63) Qian, E. A.; Han, Y.; Messina, M. S.; Maynard, H. D.; Král, P.; Spokoyny, A. M. Multivalent Cluster Nanomolecules for Inhibiting Protein-Protein Interactions. Bioconjug. Chem. 2019, 30 (10), 2594-2603.

(64) Turnbull, W. B.; Kalovidouris, S. A.; Stoddart, J. F. Large Oligosaccharide-Based Glycodendrimers.
Chem. - A Eur. J. 2002, 8 (13), 2988-3000.

Munoz, E. M.; Correa, J.; Riguera, R.; Fernandez-

Megia, E. Real-Time Evaluation of Binding Mechanisms in Multivalent Interactions: A Surface Plasmon Resonance Kinetic Approach. J. Am. Chem. Soc. 2013, 135 (16), 5966-5969.

(66) Disney, M. D.; Zheng, J.; Swager, T. M.; Seeberger, P. H. Detection of Bacteria with CarbohydrateFunctionalized Fluorescent Polymers. J. Am. Chem. Soc. 2004, 126 (41), 13343-13346.

(67) Polizzotti, B. D.; Kiick, K. L. Effects of Polymer Structure on the Inhibition of Cholera Toxin by Linear Polypeptide-Based Glycopolymers. Biomacromolecules 2006, 7 (2), 483-490.

(68) Smith, A. M.; Marbella, L. E.; Johnston, K. A.; Hartmann, M. J.; Crawford, S. E.; Kozycz, L. M.; Seferos, D. S.; Millstone, J. E. Quantitative Analysis of Thiolated Ligand Exchange on Gold Nanoparticles Monitored by ${ }^{1} \mathrm{H}$ NMR Spectroscopy. Anal. Chem. 2015, 87 (5), 27712778.

(69) Hostetler, M. J.; Templeton, A. C.; Murray, R. W. Dynamics of Place-Exchange Reactions on Monolayer-Protected Gold Cluster Molecules. Langmuir 1999, 15 (11), 3782-3789.

(70) Wixtrom, A. I.; Parvez, Z. A.; Savage, M. D.; Qian, E. A.; Jung, D.; Khan, S. I.; Rheingold, A. L.; Spokoyny, A. M. Tuning the Electrochemical Potential of Perfunctionalized Dodecaborate Clusters through Vertex Differentiation. Chem. Commun. 2018, 54 (46), 5867-5870.

(71) Wixtrom, A. I.; Shao, Y.; Jung, D.; Machan, C. W.; Kevork, S. N.; Qian, E. A.; Axtell, J. C.; Khan, S. I.; Kubiak, C. P.; Spokoyny, A. M. Rapid Synthesis of Redox-Active Dodecaborane $\mathrm{B}_{12}(\mathrm{OR})_{12}$ Clusters Under Ambient Conditions. Inorg. Chem. Front. 2016, 3, 711-717.

(72) Lee, M. W.; Farha, O. K.; Hawthorne, M. F.; Hansch, C. H. Alkoxy Derivatives of Dodecaborate: Discrete Nanomolecular Ions with Tunable Pseudometallic Properties. Angew. Chem. Int. Ed. 2007, 46 (17), 3018-3022.

(73) Barton, J. L.; Wixtrom, A. I.; Kowalski, J. A.; Qian, E. A.; Jung, D.; Brushett, F. R.; Spokoyny, A. M. Perfunctionalized Dodecaborate Clusters as Stable Metal-Free Active Materials for Charge Storage. ACS Appl. Energy Mater. 2019, 2, 49074913.

(74) Farha, O. K.; Julius, R. L.; Lee, M. W.; Huertas, R. E.; Knobler, C. B.; Hawthorne, M. F. Synthesis of Stable Dodecaalkoxy Derivatives of Hypercloso-B 12H12. J. Am. Chem. Soc. 2005, 127 (51), 1824318251.

(75) Kiessling, L. L.; Gestwicki, J. E.; Strong, L. E. Synthetic Multivalent Ligands as Probes of Signal Transduction. Angew. Chem. Int. Ed. 2006, 45 (15), 2348-2368.

(76) Bernardi, A.; Jiménez-Barbero, J.; Casnati, A.; De Castro, C.; Darbre, T.; Fieschi, F.; Finne, J.; Funken, 
H.; Jaeger, K. E.; Lahmann, M.; Lindhorst, T. K.; Marradi, M.; Messner, P.; Molinaro, A.; Murphy, P. V.; Nativi, C.; Oscarson, S.; Penadés, S.; Peri, F.; Pieters, R. J.; Renaudet, O.; Reymond, J. L.; Richichi, B.; Rojo, J.; Sansone, F.; Schäffer, C.; Turnbull, W. B.; Velasco-Torrijos, T.; Vidal, S.; Vincent, S.; Wennekes, T.; Zuilhof, H.; Imberty, A. Multivalent Glycoconjugates as Anti-Pathogenic Agents. Chem. Soc. Rev. 2013, 42 (11), 47094727.

(77) Müller, C.; Despras, G.; Lindhorst, T. K. Organizing Multivalency in Carbohydrate Recognition. Chem. Soc. Rev. 2016, 45 (11), 3275-3302.

(78) Deniaud, D.; Julienne, K.; Gouin, S. G. Insights in the Rational Design of Synthetic Multivalent Glycoconjugates as Lectin Ligands. Org. Biomol. Chem. 2011, 9 (4), 966-979.

(79) Lundquist, J. J.; Toone, E. J. The Cluster Glycoside Effect. Chem. Rev. 2002, 102 (2), 555-578.

(80) Qian, E. A.; Han, Y.; Messina, M. S.; Maynard, H. D.; Král, P.; Spokoyny, A. M. Multivalent Cluster Nanomolecules for Inhibiting Protein-Protein Interactions. Bioconjug. Chem. 2019, 30 (10), 2594-2603.

(81) Mammen, M.; Choi, S.-K.; Whitesides, G. M. Polyvalent Interactions in Biological Systems: Implications for Design and Use of Multivalent Ligands and Inhibitors. ChemInform 2010, 30 (9), 2454-2794.

(82) Bhatia, S.; Camacho, L. C.; Haag, R. Pathogen
Inhibition by Multivalent Ligand Architectures. J. Am. Chem. Soc. 2016, 138 (28), 8654-8666.

(83) Recent examples: (a) Schlatzer, T.; Kriegesmann, J.; Schröder, H.; Trobe, M.; Lembacher-Fadum, C.; Santner, S.; Kravchuk, A. V.; Becker, C. F. W.; Breinbauer, R. Labeling and Natural PostTranslational Modification of Peptides and Proteins via Chemoselective Pd-Catalyzed Prenylation of Cysteine. J. Am. Chem. Soc. 2019, 141 (37), 14931-14937; (b) Jbara, M.; Maity, S. K.; Brik, A. Palladium in the Chemical Synthesis and Modification of Proteins. Angew. Chemie - Int. Ed. 2017, 56 (36), 10644-10655; (c) de Bruijn, A. D.; Roelfes, G. Catalytic Modification of Dehydroalanine in Peptides and Proteins by Palladium-Mediated Cross-Coupling. Chem. - A Eur. J. 2018, 24 (48), 12728-12733; (d) Miller, M. K.; Wang, H.; Hanaya, K.; Zhang, O.; Berlaga, A.; Ball, Z. T. Copper-Mediated Peptide Arylation Selective for the N-Terminus. Chem. Sci. 2020, 11 (38), 10501-10505; (e) Vinogradova, E. V. Organometallic Chemical Biology: An Organometallic Approach to Bioconjugation. Pure Appl. Chem. 2017, 89, 1619-1640; (f) Kubota, K.; Dai, P.; Pentelute, B. L.; Buchwald, S. L. Palladium Oxidative Addition Complexes for Peptide and Protein Cross-Linking. J. Am. Chem. Soc. 2018, 140, 3128-3133.

\section{Insert Table of Contents artwork here}

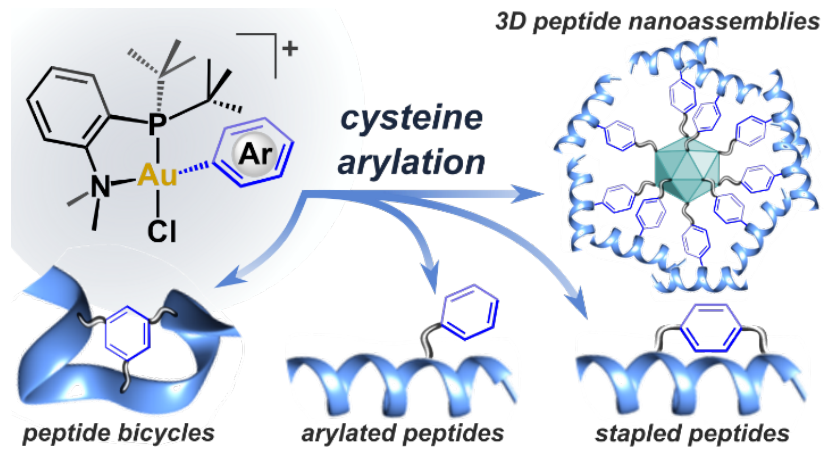

TOC synopsis: Organometallic Au(III) complexes that allow access to hybrid peptide-based assemblies of high structural diversity and complexity via cysteine $S$-arylation. 